\title{
Comparison of benthic bacterial community composition in nine streams
}

\author{
Xueqing Gao ${ }^{1,2}$, Ola A. Olapade ${ }^{1,3}$, Laura G. Leff ${ }^{1, *}$ \\ ${ }^{1}$ Department of Biological Sciences, Kent State University, Kent, Ohio 44242, USA \\ ${ }^{2}$ Present address: Florida Department of Environmental Protection, 2600 Blair Stone Road, Tallahassee, Florida 32399, USA \\ ${ }^{3}$ Present address: Wisconsin Aquatic Technology \& Environmental Research, Great Lakes WATER Institute, \\ University of Wisconsin, Milwaukee, Wisconsin 53204, USA
}

\begin{abstract}
In this study, the abundance of major bacterial taxa (based on fluorescent in situ hybridization, FISH) and the structure of the bacterial community (based on denaturing gradient gel electrophoresis, DGGE) were determined in the benthos of 9 streams in the southeastern and midwestern United States and related to differences in environmental conditions. Taxa examined via FISH were Domain Bacteria, Domain Archaea, $\alpha-, \beta$-, and $\gamma$-Proteobacteria, a portion of the Bacteroidetes (formerly Cytophaga-Flavobacterium-Bacteroides), and Gram-positive bacteria with high (actinobacteria) and low percent guanine + cytosine (GC) content. Of these taxa, generally the most abundant were the $\beta$ - and $\alpha$-Proteobacteria, which constituted on average 19.5 and $17.0 \%$ of the Domain Bacteria, respectively. Abundance of most taxa was significantly different among streams and sites within a stream. Based on canonical correspondence and correlation analyses, $\beta$ - and $\gamma$-Proteobacteria tended to be most abundant at sites with high dissolved organic carbon (DOC) and nitrate/nitrite concentrations and high benthic organic matter content. In contrast, $\alpha$-Proteobacteria were more abundant in environments with low DOC and nitrate/nitrite concentrations and low sediment organic carbon content. The other taxa did not exhibit clear correlations with the environmental variables measured. DGGE results revealed that the structure of the bacterial community differed among the streams examined, with limited differences in a given stream and much larger differences among streams. Overall, there were clear differences in community composition that in some cases correlated with differences in environmental conditions.
\end{abstract}

KEY WORDS: Bacteria · Fluorescent in situ hybridization · Denaturing gradient gel electrophoresis · Proteobacteria $\cdot$ Streams $\cdot$ Benthos

Resale or republication not permitted without written consent of the publisher

\section{INTRODUCTION}

Examination of bacterial community structure in freshwater habitats reveals not only information concerning most abundant taxa but also strong spatiotemporal changes (e.g. Lemke et al. 1997a, Leff 2000, Battin et al. 2001, McNamara et al. 2002, Pearce 2003, McNamara \& Leff 2004). Despite recent advances in our understanding of freshwater bacterial ecology, there is still a paucity of information on lotic systems (Leff 2002), with most studies reporting data from only one or, at most, a couple of ecosystems (e.g. Leff 2000, McNamara et al. 2002). Thus, we do not have data concerning the extent of differences in bacterial communities in different streams or regional differences in stream bacterial communities. Gaining an understanding of the degree of interstream variation relative to variation within a given stream is necessary for combining studies of different systems to create a comprehensive representation of trends in stream bacterial communities. If variation in bacterial community structure among streams is comparatively high, it will be not only difficult but inappropriate to draw generalities from studies in only a few ecosystems.

In this study, benthic bacterial community structure was compared among 9 streams in different geographic 
regions (the southeastern and midwestern US) and observations were related to differences in environmental conditions in the streams. The abundance of major taxonomic groups, Domain Bacteria, Domain Archaea, $\alpha-, \beta-$, and $\gamma$-Proteobacteria, a portion of the Bacteroidetes (formerly Cytophaga-Flavobacterium-Bacteroides), and Gram-positive bacteria with high (HGC) and low (LGC) percent guanine+cytosine (GC) content, was determined. These taxa were selected because of their documented occurrence in other streams (e.g. Šimek et al. 2001, Araya et al. 2003). In addition, bacterial community structure was examined using denaturing gradient gel electrophoresis (DGGE) (Muyzer et al. 1993), and within-stream variability was assessed.

From prior studies on freshwater bacterial communities several trends emerge related to the occurrence of the taxa examined in this study. Specifically, Proteobacteria (particularly $\alpha, \beta$, and $\gamma$ subclasses), CytophagaFlavobacteria (Bacteroidetes), and Actinobacteria (HGC Gram-positive bacteria) are prevalent in lakes and streams (Gloeckner et al. 2000, Battin et al. 2001, Šimek et al. 2001, Trusova \& Gladyshev 2002, Zwart et al. 2002, Araya et al. 2003, Zwisler et al. 2003). In particular, $\beta$-Proteobacteria are common in both oligotrophic and eutrophic freshwater systems (Šimek et al. 2001, Araya et al. 2003, Zwisler et al. 2003), while $\alpha$ Proteobacteria appear to be less abundant in freshwater ecosystems and may prefer labile dissolved organic matter (DOM) (Zwisler et al. 2003). CytophagaFlavobacteria are most commonly associated with the occurrence of recalcitrant, high molecular weight DOM (Kirchman 2001, Zwisler et al. 2003) and are prevalent on particulate matter (Selje \& Simon 2003).

The 9 streams examined in this study differ in many environmental features, including sources and amounts of DOM and inorganic nutrient concentrations (Webster \& Meyer 1997, Gao et al. 2004, Olapade et al. 2005), both of which were hypothesized to potentially generate differences in bacterial community composition. Three of the streams are blackwater streams (with high amounts of humic materials) of the US coastal plain (Georgia and Virginia, which are well canopied, and South Carolina). A well-canopied Appalachian Mountain region stream (North Carolina) was also sampled in the southeastern USA. In the Midwest, a prairie stream (Kansas), a 'corn belt' stream (Iowa), and 2 upper midwestern streams (Michigan and Wisconsin) were sampled along with a wellcanopied stream in Ohio.

\section{MATERIALS AND METHODS}

Sampling sites. Sediment samples were collected from 9 streams: Meyers Branch in South Carolina (MB-
SC, located on the Savannah River Plant; McArthur et al. 1992, Koetsier et al. 1997), Black Creek in Georgia (BC-GA; Leff \& Meyer 1991, Leff 2000), Hugh White Creek in North Carolina (HWC-NC, located at the Coweeta NSF Long-Term Ecological Research [LTER] site; Webster et al. 1997), Buzzard's Branch in Virginia (BB-VA; Smock 1997), Allequash Creek in Wisconsin (AC-WI, located at the North Temperate Lakes LTER; Meyer et al. 1993), Augusta Creek in Michigan (AuCMI, located at the Kellogg Biological State LTER; Manny \& Wetzel 1973, Bott et al. 1985), Buffalo Creek in Iowa (BuC-IA), King's Creek in Kansas (KC-KS, located at the Konza Prairie LTER, McArthur \& Marzolf 1986, Gray 1997), and the West Branch of the Mahoning River in Ohio (WB-OH; Lemke et al. 1997c, Leff et al. 1998). These streams are second to third order and were chosen based on prior studies and differences in their sources and quantities of organic matter (OM) (Webster \& Meyer 1997, Gao et al. 2004). Samples were collected during the summer of 2001 from June through August.

Sample collection. Samples were collected from 3 sites along the mid-channel of each stream (referred to as Sites A, B, and C for a given stream). These sites were 100 to $1000 \mathrm{~m}$ apart. Five replicate sediment samples were collected at each sampling site from the top $5 \mathrm{~cm}$ of the stream bottom (in total, 135 samples were collected). For bacterial enumeration, about $9 \mathrm{~g}$ of sediment from each replicate was put into a $50 \mathrm{ml}$ Falcon tube and fixed with $36 \mathrm{ml}$ PBS-paraformaldehyde (phosphate-buffered saline $+8 \%$ paraformaldehyde; Lemke et al. 1997b). Upon returning to the lab, $12 \mathrm{ml}$ sodium pyrophosphate $(0.1 \%)$ was added, and samples were sonicated for $5 \mathrm{~min}$ (Branson Model 2210 ultrasonic bath, Ultrasonics). Samples for DNA extraction were mixed with Tris-EDTA and frozen at $-70^{\circ} \mathrm{C}$ until processing.

Physical and chemical variables. Selected physical and chemical variables were measured in triplicate at each site. Nitrate/nitrite was determined using a Hach colorimeter-nitrate (model DR100). Soluble reactive phosphorus (SRP) concentration was measured using a Hach colorimeter-phosphorus (model DR100). pH was measured using an Oakton meter. Dissolved organic carbon (DOC) concentration was determined using a Shimaszu TDC-5000 carbon analyzer. Chlorophyll a concentration was determined via the standard spectrophotometric method (APHA 1996). The percentage of OM of the sediment samples was determined based on the difference between the dry wt and ash wt divided by the dry wt and multiplied by 100 . The particle size distribution of sediment samples was analyzed by fractionating the samples via sieving into different size classes (>1 mm, 0.5-1 mm, 0.1-0.5 mm, $0.01-0.1 \mathrm{~mm}$, and $<0.01 \mathrm{~mm}$ ). 
Fluorescent in situ hybridization (FISH). Abundance of Domain Bacteria, Domain Archaea, $\alpha-, \beta-$, and $\gamma$ Proteobacteria, a portion of the Bacteroidetes group (in the interest of consistency with other papers, cells hybridizing this probe will henceforth be referred to as CFB), HGC and LGC Gram-positive bacteria were determined using the FISH procedure of Lemke et al. (1997b). Sediment slurry (diluted 1000 times) was filtered through a $0.2 \mu \mathrm{m}$ Whatman Anodisc membrane, rinsed with $1 \mathrm{ml}$ deionized water and $1 \mathrm{ml} 0.1 \%$ Nonidet P-40 (Sigma), and incubated with $40 \mu \mathrm{l}$ corresponding Texas-red-labeled oligonucleotide probe (Sigma Genosys) ( $5 \mathrm{ng} \mathrm{pl}^{-1}$ in hybridization buffer [ $6 \times$ SSC, $0.02 \mathrm{M}$ Tris buffer, $\mathrm{pH} 7,0.1 \%$ SDS, and $0.01 \%$ poly A]) at the specified temperature for $4 \mathrm{~h}$. Hybridized cells were then rinsed 2 times with $1 \mathrm{ml}$ washing buffer $(\mathrm{NaCl} 0.9 \mathrm{M}$, Tris $\mathrm{pH} 7.20 .02 \mathrm{M}$, SDS $0.1 \%$, and water) and $1 \mathrm{ml}$ deionized water, air dried, and mounted with type FF nonfluorescent immersion oil (R. P. Cargille Laboratories). Bacterial cells were enumerated via epifluorescence microscopy; at least 200 cells were enumerated and the minimum number of fields examined was 10.

Depending on the probe used, $\mathrm{NaCl}$ concentration of the washing buffer was varied to achieve the highest specificity. For Domain Bacteria and Domain Archaea, $\alpha$-Proteobacteria, and HGC and LGC Gram-positive probes, $0.9 \mathrm{M} \mathrm{NaCl}$ was used, and for the other probes $0.009 \mathrm{M} \mathrm{NaCl}$ was used. Thirty percent formamide was used in the hybridization buffer of $\beta$ - and $\gamma$-Proteobacteria and CFB to achieve high specificity. Formamide caused strong background autofluorescence if we used Anodisc filters; thus white $0.2 \mu \mathrm{m}$ polycarbonate filters were used. Sequences of the probes and hybridization temperatures are listed in Table 1.

Denaturing gradient gel electrophoresis. DNA extraction, PCR, and DGGE were performed as described in Cody et al. (2000) and Xu \& Leff (2004). Briefly, DNA was extracted following the method of Zhou et al. (1996) and purified using Sephadex G-200 (Tsai \& Olson 1992).
PCR was performed using 968F+GC clamp (5'-GCCCCGCCGCGCGCGGCGGGCGGGGCGGGGGACG GGGGGAACGCGAAGAACCTTAC-3'; Heuer \& Smalla 1997) and 1392R (5'-ACGGGCGGTGTGTRC3'; Brosius et al. 1981). PCR reaction mixtures were prepared using $1 \mu \mathrm{l}$ of DNA extract, $68.5 \mu \mathrm{l}$ water, $10 \mu \mathrm{l}$ of $10 \mathrm{X}$ PCR buffer (with $15 \mathrm{mM} \mathrm{MgCl}_{2}$ ), $2.5 \mu \mathrm{l}$ of $100 \mu \mathrm{M}$ Bovine Serum Albumin, $16 \mu \mathrm{l}$ of dNTPs $(1.25 \mathrm{mM})$, and $1 \mu \mathrm{l}$ of each primer. A hot start protocol was followed and $1 \mu \mathrm{l}$ of Expand High Fidelity PCR system enzyme (Roche) was used. PCR amplification was performed using 40 cycles and a temperature touch-down scheme (van Elsas \& Wolters 1995) with a PTC-100 TM Programmable Thermal Controller (MJ Research).

Six percent polyacrylamide gels with a 40 to $70 \%$ denaturant range $(100 \%=7 \mathrm{M}$ urea and $40 \%$ formamide) were used for DGGE. Gels were run using the D-code system (Bio-Rad) for $8 \mathrm{~h}$ at $170 \mathrm{~V}$ and stained with Syber Green I (Molecular Probes). Gel images were taken using a Hamamatsu C5985 chilled CCD camera and analyzed using GelPro 3.0 (Media Cybernetics).

Statistical analyses. Data were analyzed using nested ANOVAs (sites nested within streams). Ordination was performed via canonical correspondence analysis (CCA; MVSP 3.0, Kovach Computing Services; ter Braak 1988) to examine relationships between bacterial assemblage differences among streams and environmental variables; correlations were used to examine relationships between specific pairs of variables.

\section{RESULTS}

Physical and chemical variables differed among sampling sites (Table 2). SRP concentration ranged from about 0.08 to $0.48 \mu \mathrm{g} \mathrm{l}^{-1}$. Low SRP concentrations were observed at the $3 \mathrm{SC}$ sites and Site A of the KS stream. Site A of the GA stream and Site C of the IA

Table 1. Sequences of the oligonucleotide probes (reviewed by Amann et al. 1995) and hybridization temperature used

\begin{tabular}{|llcc|}
\hline Taxon & Sequence & $\begin{array}{c}\text { Hybridization } \\
\text { temp. }\left({ }^{\circ} \mathrm{C}\right)\end{array}$ & Source \\
\hline Domain Bacteria & GCTGCCTCCCGTAGGAGT & 48 & Amann et al. (1990) \\
Domain Archaea & GTGCTCCCCCGCAATCCT & 45.5 & Stahl \& Amann (1991) \\
$\alpha$-Proteobacteria & CGTTCG(C/T)CTGAGCCAG & 54 & Manz et al. (1992) \\
$\beta$-Proteobacteria & GCCTTCCCACTTCGTT & 50 & Manz et al. (1992) \\
$\gamma$-Proteobacteria & GCCTTCCCACATCGTTT & 57 & Manz et al. (1992) \\
Cytophaga-Flavobacteria & TGGTCCGTGTCTCAGTAC & 52 & Amann et al. (1995) \\
Gram-positive high GC bacteria & ATAGTTACCACCGCCGT & 48 & Meier et al. (1994) (1999) \\
Gram-positive low GC bacteria & YSGAAGATTCCCTACTGC & 46 & \\
\hline
\end{tabular}


Table 2. Environmental variables measured at studied sites (Gao et al. 2004, Olapade et al. 2005). OM: percent organic matter content of sediment samples. Values represent mean $\pm 1 \mathrm{SE}(\mathrm{n}=3)$

\begin{tabular}{|c|c|c|c|c|c|c|c|}
\hline Stream, location & Site & $\begin{array}{c}\text { SRP } \\
\left(\mu{\left.\mathrm{P} \mathrm{l}^{-1}\right)}^{-1}\right.\end{array}$ & $\begin{array}{l}\mathrm{NO}_{3} / \mathrm{NO}_{2} \\
\left(\mu \mathrm{N} \mathrm{l}^{-1}\right)\end{array}$ & $\begin{array}{c}\mathrm{DOC} \\
\left(\mathrm{mg} \mathrm{l}^{-1}\right)\end{array}$ & $\mathrm{pH}$ & $\begin{array}{c}\text { Sed. chl a } \\
\left(\mu g^{-1}\right)\end{array}$ & $\begin{array}{l}\text { OM } \\
(\%)\end{array}$ \\
\hline \multirow[t]{3}{*}{ Meyers Branch, SC } & $\mathrm{SC}-\mathrm{A}$ & $0.08 \pm 0.00$ & $0.06 \pm 0.01$ & $11.48 \pm 0.74$ & $7.13 \pm 0.09$ & $0.12 \pm 0.04$ & $0.42 \pm 0.08$ \\
\hline & SC-B & $0.11 \pm 0.00$ & $0.05 \pm 0.00$ & $6.51 \pm 0.77$ & $6.52 \pm 0.08$ & $0.09 \pm 0.03$ & $1.21 \pm 0.83$ \\
\hline & $\mathrm{SC}-\mathrm{C}$ & $0.09 \pm 0.00$ & $0.06 \pm 0.00$ & $10.02 \pm 2.01$ & $6.53 \pm 0.07$ & $0.06 \pm 0.03$ & $0.81 \pm 0.19$ \\
\hline \multirow[t]{3}{*}{ Black Creek, GA } & GA-A & $0.48 \pm 0.09$ & $0.00 \pm 0.00$ & $35.05 \pm 1.31$ & $5.74 \pm 0.05$ & $0.46 \pm 0.14$ & $0.42 \pm 0.11$ \\
\hline & GA-B & $0.18 \pm 0.04$ & $0.00 \pm 0.00$ & $19.47 \pm 0.69$ & $5.56 \pm 0.04$ & $0.39 \pm 0.06$ & $1.12 \pm 0.22$ \\
\hline & GA-C & $0.25 \pm 0.03$ & $0.00 \pm 0.00$ & $10.62 \pm 0.30$ & $5.40 \pm 0.06$ & $1.87 \pm 0.74$ & $1.01 \pm 0.25$ \\
\hline \multirow[t]{3}{*}{ Hugh White Creek, NC } & NC-A & $0.33 \pm 0.03$ & $0.03 \pm 0.00$ & $0.10 \pm 0.02$ & $6.18 \pm 0.14$ & $0.10 \pm 0.07$ & $1.76 \pm 0.15$ \\
\hline & NC-B & $0.20 \pm 0.03$ & $0.02 \pm 0.00$ & $1.38 \pm 0.06$ & $6.11 \pm 0.14$ & $0.04 \pm 0.00$ & $1.65 \pm 0.15$ \\
\hline & $\mathrm{NC}-\mathrm{C}$ & $0.18 \pm 0.04$ & $0.03 \pm 0.01$ & $1.25 \pm 0.05$ & $6.89 \pm 0.20$ & $0.09 \pm 0.01$ & $1.42 \pm 0.10$ \\
\hline \multirow[t]{3}{*}{ Buzzard's Branch, VA } & VA-A & $0.29 \pm 0.08$ & $0.96 \pm 0.00$ & $5.97 \pm 0.23$ & $6.66 \pm 0.02$ & $0.13 \pm 0.01$ & $0.55 \pm 0.06$ \\
\hline & VA-B & $0.20 \pm 0.05$ & $0.96 \pm 0.02$ & $5.95 \pm 0.16$ & $6.52 \pm 0.04$ & $0.15 \pm 0.04$ & $0.79 \pm 0.16$ \\
\hline & VA-C & $0.38 \pm 0.06$ & $0.92 \pm 0.06$ & $6.30 \pm 0.42$ & $5.65 \pm 0.31$ & $0.21 \pm 0.12$ & $0.45 \pm 0.06$ \\
\hline \multirow[t]{3}{*}{ Allequash Creek, WI } & WI-A & $0.28 \pm 0.02$ & $0.02 \pm 0.00$ & $7.55 \pm 0.48$ & $6.87 \pm 0.04$ & $1.65 \pm 0.56$ & $0.51 \pm 0.10$ \\
\hline & WI-B & $0.30 \pm 0.00$ & $0.02 \pm 0.00$ & $6.65 \pm 0.07$ & $7.08 \pm 0.09$ & $0.79 \pm 0.12$ & $3.80 \pm 1.41$ \\
\hline & WI-C & $0.23 \pm 0.03$ & $0.02 \pm 0.00$ & $8.14 \pm 0.43$ & $6.81 \pm 0.11$ & $2.79 \pm 0.82$ & $0.79 \pm 0.09$ \\
\hline \multirow[t]{3}{*}{ Augusta, MI } & MI-A & $0.37 \pm 0.03$ & $0.41 \pm 0.02$ & $8.29 \pm 0.09$ & $7.88 \pm 0.04$ & $1.48 \pm 0.32$ & $1.50 \pm 0.64$ \\
\hline & MI-B & $0.37 \pm 0.03$ & $0.45 \pm 0.03$ & $9.55 \pm 0.30$ & $7.67 \pm 0.03$ & $0.43 \pm 0.20$ & $3.98 \pm 1.69$ \\
\hline & MI-C & $0.43 \pm 0.03$ & $0.58 \pm 0.02$ & $10.36 \pm 1.15$ & $7.85 \pm 0.12$ & $1.47 \pm 0.27$ & $0.76 \pm 0.42$ \\
\hline \multirow[t]{3}{*}{ Buffalo Creek, IA } & IA-A & $0.20 \pm 0.00$ & $6.80 \pm 0.15$ & $17.60 \pm 0.59$ & $6.84 \pm 0.07$ & $0.82 \pm 0.11$ & $3.18 \pm 0.23$ \\
\hline & IA-B & $0.31 \pm 0.02$ & $4.93 \pm 0.03$ & $33.31 \pm 1.48$ & $7.22 \pm 0.01$ & $0.62 \pm 0.16$ & $2.40 \pm 0.57$ \\
\hline & IA-C & $0.47 \pm 0.02$ & $4.17 \pm 1.17$ & $33.03 \pm 1.15$ & $7.50 \pm 0.02$ & $0.98 \pm 0.16$ & $0.26 \pm 0.05$ \\
\hline \multirow[t]{3}{*}{ King's Creek, KS } & KS-A & $0.11 \pm 0.01$ & $0.03 \pm 0.00$ & $22.37 \pm 1.88$ & $7.75 \pm 0.02$ & $0.22 \pm 0.04$ & $3.10 \pm 0.19$ \\
\hline & KS-B & $0.18 \pm 0.02$ & $0.02 \pm 0.00$ & $11.73 \pm 0.06$ & $7.52 \pm 0.01$ & $0.27 \pm 0.04$ & $0.77 \pm 0.10$ \\
\hline & $\mathrm{KS}-\mathrm{C}$ & $0.18 \pm 0.01$ & $0.31 \pm 0.08$ & $14.17 \pm 1.54$ & $7.52 \pm 0.02$ & $0.95 \pm 0.36$ & $1.00 \pm 0.09$ \\
\hline \multirow{3}{*}{ West Branch Mahoning River, OH } & $\mathrm{OH}-\mathrm{A}$ & $0.14 \pm 0.01$ & $0.03 \pm 0.01$ & $7.50 \pm 0.03$ & $7.67 \pm 0.04$ & $1.61 \pm 0.09$ & $2.01 \pm 0.69$ \\
\hline & $\mathrm{OH}-\mathrm{B}$ & $0.17 \pm 0.04$ & $0.03 \pm 0.01$ & $8.70 \pm 0.26$ & $7.57 \pm 0.03$ & $0.81 \pm 0.09$ & $0.97 \pm 0.29$ \\
\hline & $\mathrm{OH}-\mathrm{C}$ & $0.18 \pm 0.02$ & $0.15 \pm 0.02$ & $7.88 \pm 0.11$ & $7.62 \pm 0.02$ & $1.74 \pm 0.32$ & $1.46 \pm 0.17$ \\
\hline
\end{tabular}

stream (in a highly agricultural area) had the highest SRP concentration. Nitrate/nitrite concentration varied widely among streams and ranged from undetectable in the GA stream to higher than $6 \mu \mathrm{g} \mathrm{N}^{-1}$ in the agricultural IA stream. DOC concentration ranged from about $1 \mathrm{mg} \mathrm{l}^{-1}$ in the $\mathrm{NC}$ stream to more than $30 \mathrm{mg} \mathrm{l}^{-1}$ in the blackwater GA stream and the IA stream. $\mathrm{pH}$ was relatively constant among different stream sites and ranged from 5.40 to about 7.88. The lowest $\mathrm{pH}$ was observed at the 3 sites in the GA stream $(<6)$.

The highest benthic OM was observed at Site B of the WI stream (which had a well-developed macrophyte bed) and Site B of the MI stream (which was close to a wetland; see Table 2). In addition, high benthic OM was also observed at Sites A and B of the IA stream (which had a layer of fine black material on top of more sandy sediments, perhaps resulting from input from nearby cattle farms) and Site A of the KS stream. At the latter site, a layer of black sediment on top of the gravel base of the stream was observed, perhaps resulting from the bison that frequent that area.

Small-sized sediment particles were abundant at Sites A and B of the IA stream as a result of the layer of black organic material on top of the sandy sediment (data not shown). Small-sized sediment particles, which appeared to be macrophyte detritus, were also common at Site B of the WI stream.

The number of cells hybridizing the Domain Bacteria probe ranged from $6.49 \times 10^{7}$ cells $^{-1}$ at Site $\mathrm{C}$ of the KS stream to $2.32 \times 10^{9}$ cells g $^{-1}$ at Site A of the IA stream (Fig. 1a). Domain Bacteria counts were high at all sites in the IA stream and low at Sites B and C of the KS stream and all 3 sites in the NC stream. There were statistically significant differences among streams $(F=37.0, \mathrm{p}<0.001)$ and sites within streams $(F=9.69$, $\mathrm{p}<0.001)$.

The distribution of cells hybridizing the Domain Archaea probe in the streams was different from that of the Domain Bacteria. The number of Archaea ranged from $4.75 \times 10^{6}$ cells $\mathrm{g}^{-1}$ sediment at Site B of the KS stream to $4.99 \times 10^{7}$ cells $\mathrm{g}^{-1}$ sediment at Site C of the GA stream (Fig. 1b). There were significant differences among streams $(F=5.94, \mathrm{p}<0.001)$ and among sites within a stream $(F=5.95, \mathrm{p}<0.001)$. The ratio between Archaea and Bacteria counts across all the sampling sites was between 0.005 and 0.073 .

Fig. 2 depicts the percentage of total bacterial counts accounted for by FISH with the Domain Bacteria and Archaea probes. The Domain Bacteria probe typically hybridized with less than $50 \%$ of the total cells, except 

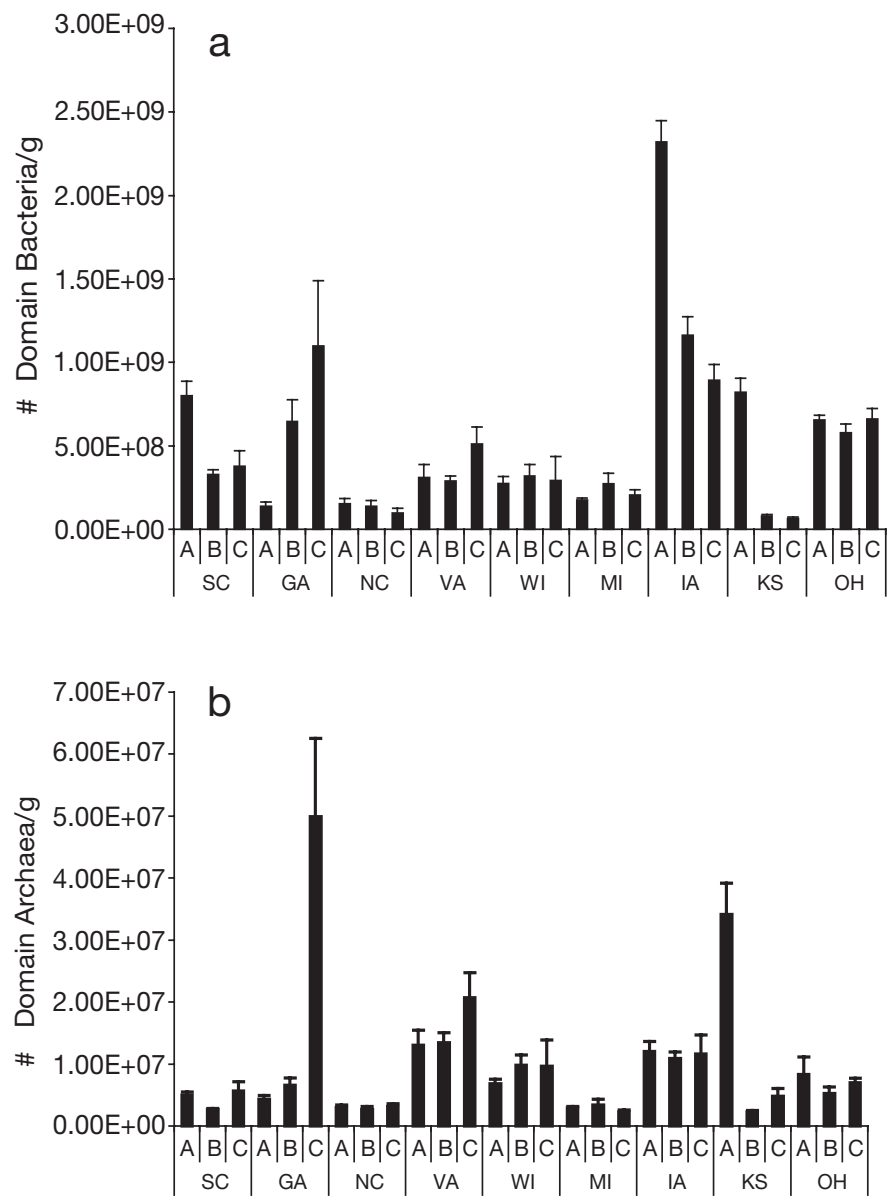

Fig. 1. Abundance of (a) Domain Bacteria and (b) Domain Archaea based on FISH in sediments of 9 streams. Samples were collected from 3 sites $(A, B, C)$ in each stream. Values are means $+\mathrm{SE}$

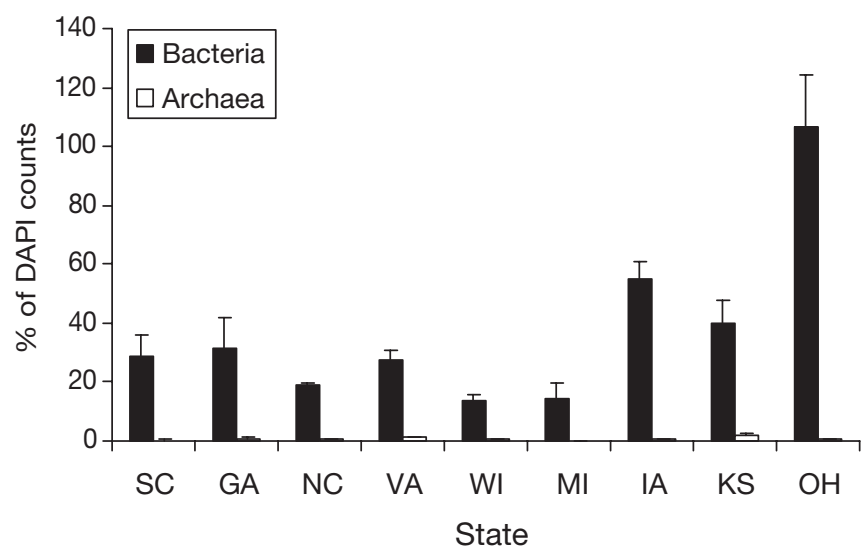

Fig. 2. Percentage of total cells (based on DAPI staining, reported in Gao et al. 2004) hybridizing with Domain Bacteria and Domain Archaea probes. Values are averages from 15 samples (5 samples from each of the 3 sites in a given stream)
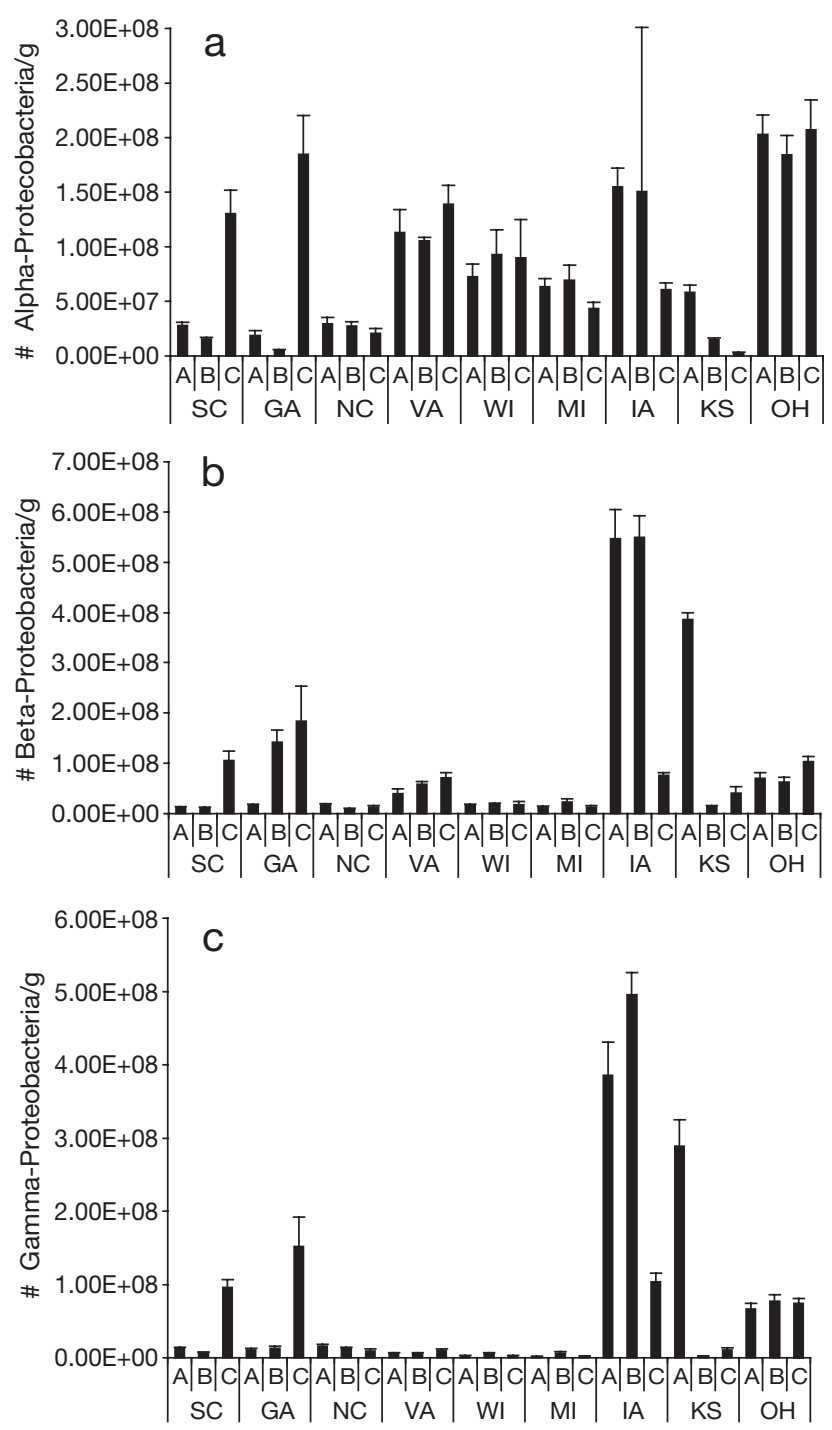

Fig. 3. Abundance of (a) $\alpha-$, (b) $\beta-$, and (c) $\gamma$-Proteobacteria based on FISH in sediments of 9 streams. Samples were collected from 3 sites $(A, B, C)$ in each stream. Values are means $+\mathrm{SE}$

in the $\mathrm{OH}$ stream, where there were much higher values. The Archaea accounted for a very small percentage of the total number of cells.

Differences in distribution were also observed among the 3 groups of Proteobacteria examined. Abundance of $\alpha$-Proteobacteria was high at several of the stream sites, especially in the $\mathrm{OH}$ stream (Fig. 3a), but did not differ significantly among streams $(F=1.62$, $\mathrm{p}>0.05)$ or among sites within a stream $(F=1.26, \mathrm{p}>$ 0.05). Lowest abundance was observed at Site $C$ of the KS stream.

The distributions of $\beta$ - and $\gamma$-Proteobacteria were similar to each other but different than that of the $\alpha$ Proteobacteria (Fig. 3b,c). For both $\beta$ - and $\gamma$-Proteo- 

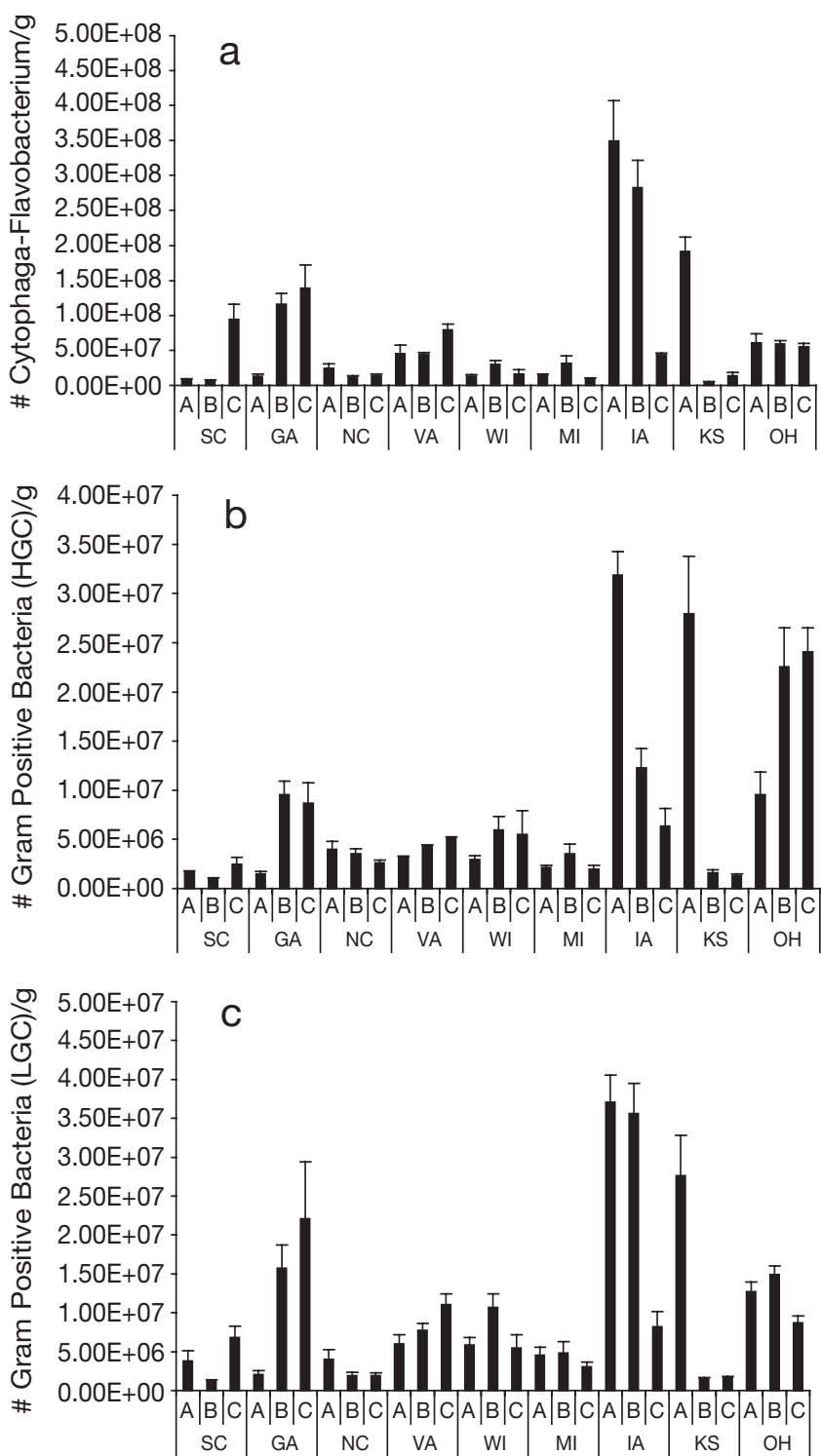

Fig. 4. Abundance of (a) Cytophaga-Flavobacteria, and (b) high (HGC) and (c) low (LGC) GC Gram-positive bacteria based on FISH in sediments of 9 streams. Samples were collected from 3 sites $(A, B, C)$ in each stream. Values are means $+\mathrm{SE}$

bacteria, the highest cell counts were at Sites A and B of the IA stream and Site A of the KS stream. There were significant differences among streams $(\beta, F=$ 21.48, $\mathrm{p}<0.001 ; \gamma, F=100.5, \mathrm{p}<0.001)$ and sites within streams $(\beta, F=8.75, \mathrm{p}<0.001 ; \gamma F=28.04, \mathrm{p}<$ $0.001)$. Relatively high numbers of $\beta$ - and $\gamma$-Proteobacteria were also observed at Site $\mathrm{C}$ of the SC and GA streams, but abundance at the other sites was very low in comparison to Sites A and B of the IA stream. The overall abundance of $\beta$ - and $\gamma$-Proteobacteria was comparable to that of $\alpha$-Proteobacteria at Sites A and B of the IA stream, Site A of the KS stream, and Site C of the SC and GA streams. At the other stream sites, $\beta$ - and $\gamma$-Proteobacteria counts were about an order of magnitude lower than $\alpha$ Proteobacteria counts.

The pattern of abundance of CFB was similar to that of the $\beta$ - and $\gamma$-Proteobacteria (Fig. 4a) and differed significantly among streams $(F=36.20, \mathrm{p}<0.001)$ and sites within streams $(F=19.25, \mathrm{p}<0.001)$. The highest CFB abundance was at Sites A and B of the IA stream and Site A of the KS stream. High cell counts were also observed at Site C of the SC stream and Sites B and C of the GA stream.

Numbers of HGC and LGC Gram-positive bacteria were about 1 order of magnitude lower than those of the other taxa examined (Fig. 4b,c). For the HGC bacteria, there were significant differences among streams $(F=24.46, \mathrm{p}<0.001)$ but not for the LGC bacteria $(F=1.88, \mathrm{p}>0.05)$. In addition, for the HGC bacteria there were significant differences among sites within streams $(F=12.90, \mathrm{p}<0.001)$ but not for the LGC bacteria $(F=1.70, \mathrm{p}>0.05)$. As for several of the other taxa, high numbers of HGC and LGC bacteria were observed at Sites A and B of the IA stream and Site A of the KS stream. High HGC counts were also found at Sites B and C of the $\mathrm{OH}$ stream. LGC abundance was also high at all 3 sites of the $\mathrm{OH}$ stream and Sites B and C of the GA stream.

In Fig. 5, the relative contribution of each taxon examined to the total number of cells hybridizing the Domain Bacteria probe is given. The LGC and HGC bacteria generally contributed little to the total. In most streams, the taxa examined accounted for at least $50 \%$ of the Domain Bacteria. In the KS stream, an especially large proportion of cells was accounted for by these taxa.

To help explain the distributions of bacterial taxa among the study streams, CCA analysis was conducted using the bacterial abundance and physical/ chemical data (Fig. 6). Two CCA axes were included: for Axis 1, differences in environmental factors explain about $42.2 \%$ of the variation in the bacterial community and Axis 2 explains another $2.5 \%$.

DOC and nitrate/nitrite concentrations, sediment OM, and chlorophyll a contents appeared to be major factors related to the abundance of the taxa examined (see Fig. 6). $\beta$ - and $\gamma$-Proteobacteria tended to be most abundant at sites with high DOC and nitrate/nitrite concentrations and high benthic OM content. In contrast, $\alpha$-Proteobacteria were more abundant in environments with low DOC and nitrate/nitrite concentrations and low sediment organic carbon content. However, abundance of these bacteria tended to be high at sites with high sediment chlorophyll a concentration. The abundances of CFB, HGC, and LGC Gram-positive bacteria appeared unrelated to the 


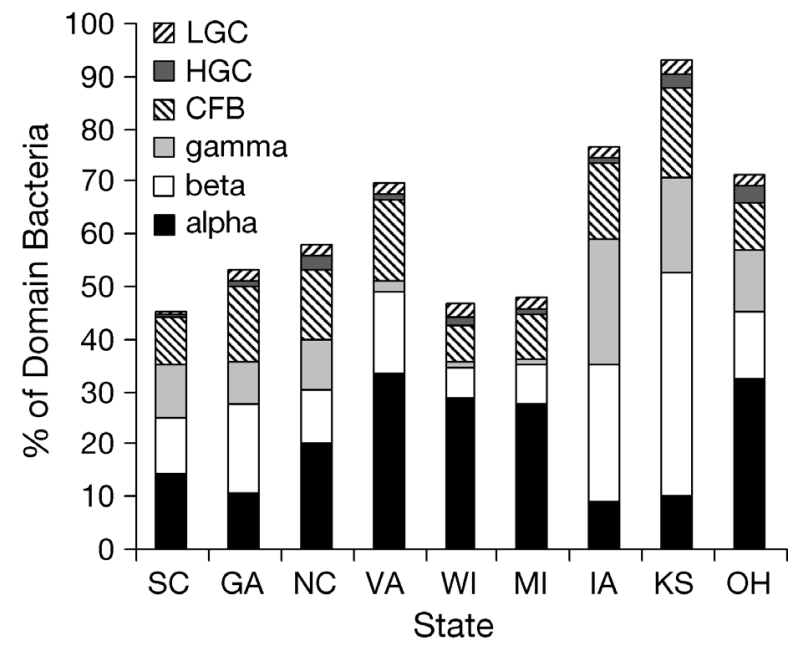

Fig. 5. Percentage of each taxon examined by FISH represented by Domain Bacteria counts. Values are averages from 15 samples $(5$ samples from each of the 3 sites in a given stream). LGC and HGC: low and high GC content Gram-positive bacteria, respectively; CFB: CytophagaFlavobacterium-Bacteroides

environmental factors examined in this study based on correlation analysis.

Clear differences in community composition among the streams sampled were evident in the DGGE results (Fig. 7). Interestingly, there was generally a high degree of similarity among the 3 sites (A, B, and C) in a given stream, and replicate samples from each site also gave highly similar patterns (data not shown). Despite good amplification of extracted DNA, we were not able to detect many bands ( 1 to 2 per site) in the SC stream,

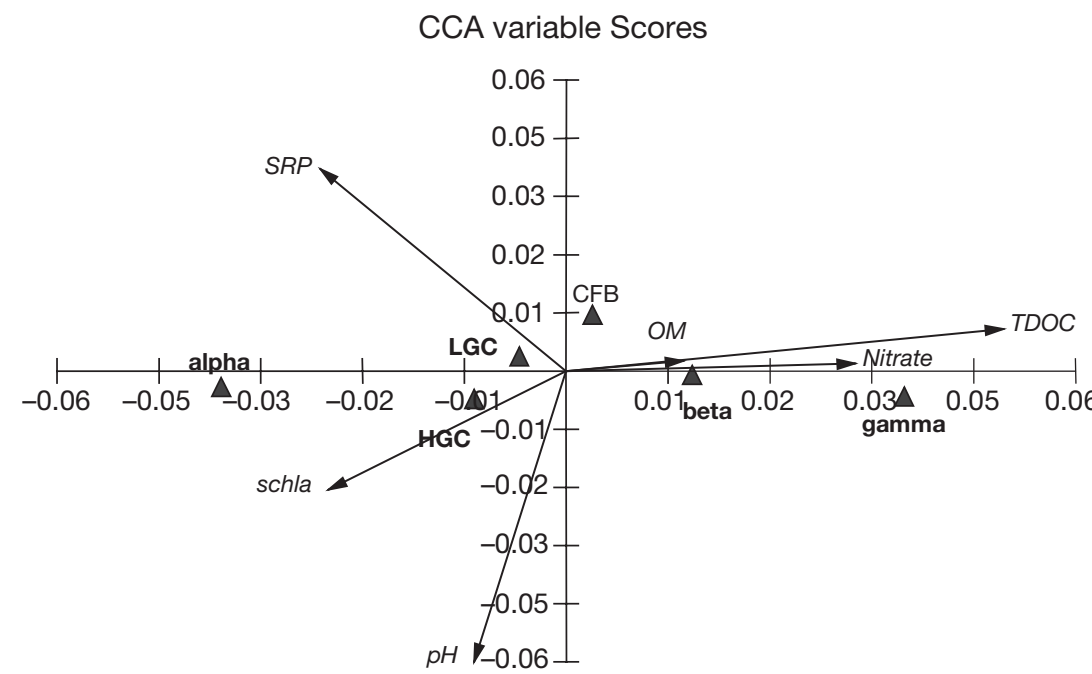

Fig. 6. Ordination results based on canonical correspondence analysis of FISH and environmental data. SRP: soluble reactive phosphorus; OM: benthic organic matter; TDOC: total dissolved organic carbon; schla: sediment chlorophyll a a blackwater stream with sandy benthos. The number of bands detected in the other streams ranged from 9 to 16 , with the greatest number of bands in the MI and VA streams. Some bands at similar locations on the gel were found in multiple streams, while others were only found in 1 or 2 streams. The average number of bands in common between any 2 streams was 3.8 and ranged from 0 (the $\mathrm{NC}$ vs. the $\mathrm{OH}$ stream) to 7 (the GA vs. the IA and WI streams). Differences among streams followed a pattern that did not appear to be related to geographic location or environmental conditions.

\section{DISCUSSION}

Cross-system studies like this one can offer insights into generalities that transcend several systems. Here, examination of differences among streams in different regions helps us assess the degree to which we are likely to be able to establish general tendencies in stream bacterial ecology. The degree of variation among the streams examined and intrastream differences depended on the method used to examine community structure. Specifically, both DGGE and FISH revealed differences among the streams examined, but intrastream variation was of greater magnitude with FISH than with DGGE.

Differences in the bacterial community among streams may be attributable to differences in environmental conditions; however, documenting these relationships has proven difficult. For example, Gao et al. (2004) reported that total bacterial number in sediments of these same streams was not linearly related to chlorophyll concentration. Likewise, when examining the abundance of 3 bacterial species in these streams Olapade et al. (2005) found that planktonic numbers for a given species correlated with certain environmental variables but that relationships were less apparent for benthic samples.

In the present study, the abundance of the $\beta$ - and $\gamma$-Proteobacteria correlated best with benthic OM content, DOC, and nitrate/nitrite concentration. The $\beta$-Proteobacteria often represent the highest proportion of the Domain Bacteria in freshwater systems (Zwisler et al. 2003), and their abundance may be related to concentration of ammonia, pollutants, or other environmental factors (Brümmer et al. 2000). In contrast, the abundance of the $\alpha$ Proteobacteria was inversely related to these variables and showed a much different pattern of abundance in the study streams. Specifically, abundance of this 


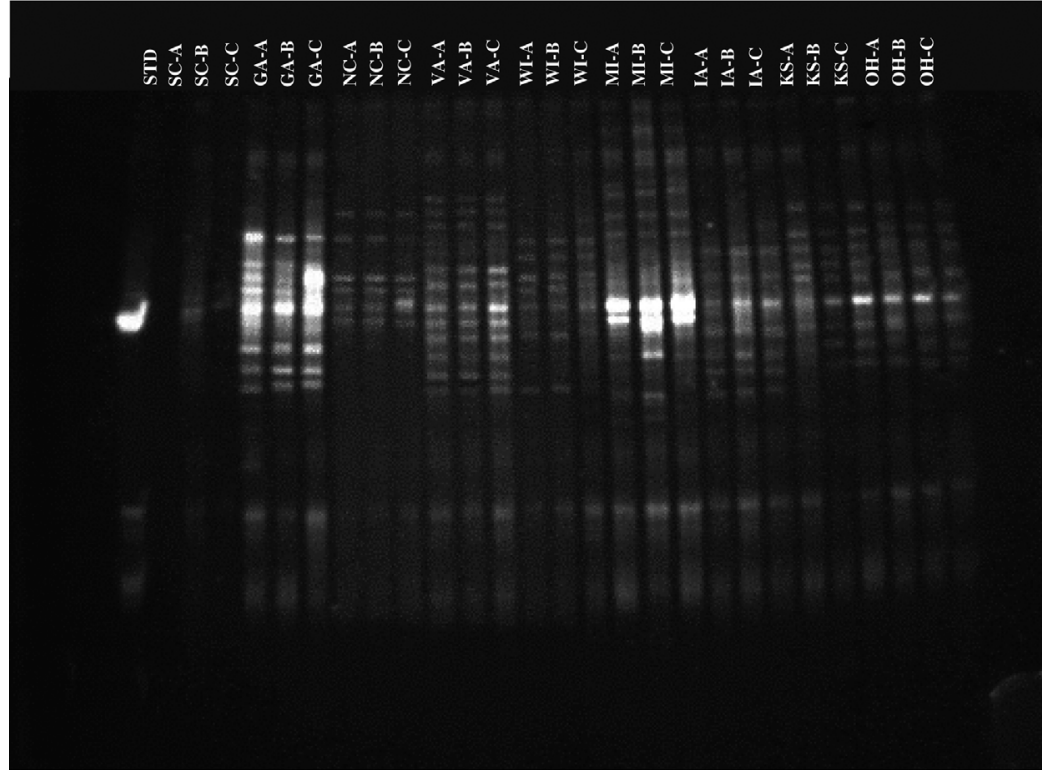

Fig. 7. DGGE image with lanes labeled with the state in which the stream was located and the site (A, B, C) within a given stream where the samples were collected (STD $=$ standard). Lanes are arranged in the order in which samples were collected from the various locations

taxon appeared to be related to chlorophyll concentrations, suggesting that these organisms depend on labile DOC produced by algae (a trend that has been documented for total bacterial numbers as well, e.g. Gao et al. 2004). A prior study showed that, in a lake, $\alpha$-Proteobacteria were more related to concentrations of labile organic compounds than other factors (Zwisler et al. 2003), and Eiler et al. (2003) experimentally demonstrated that the $\alpha$-Proteobacteria thrived at the lowest DOC concentration they examined. Moreover, Jardillier et al. (2004) found that $\alpha$-Proteobacteria were more heavily impacted by grazing than were the $\beta$ Proteobacteria. Together, these findings suggest that different factors control these different taxa.

Although numbers of HGC bacteria correlated to some degree with sediment chlorophyll concentration, the abundance of the LGC and CFB bacteria did not appear to be strongly related to the specific environmental variables measured in this study. The abundance of the CFB has been related to the occurrence of high molecular weight organic compounds (Kirchman 2001, Zwisler et al. 2003). Although we only examined overall DOC concentration in this study, differences in the streams sampled likely result in differences in the composition of the DOC pool. DOC in streams (quantity and type) can be a major factor impacting bacterial communities (McNamara \& Leff 2004, Olapade \& Leff 2005). Specifically, the blackwater streams (GA, SC, VA) have higher DOC concentrations with large amounts of recalcitrant material (Meyer 1990), in con- trast to the other streams examined. Despite these conditions, which would seem to be favorable for the CFB and other organisms, abundance in the blackwater streams was comparatively low. Much higher numbers were observed in the IA stream, whose high DOC concentrations coupled with high amounts of inorganic nutrients and benthic OM likely led to the apparent success (based on numbers) of various bacterial taxa in that stream. In addition, abundance of $\beta$ - and $\gamma$-Proteobacteria was also high in the IA stream and downstream sites in the GA and SC streams. At the latter sites, the relatively high abundances may be accounted for by the amount of DOC coupled with the extensive floodplains that are an important source of allochthonous cells (Leff et al. 1993)

Examination of the relative contributions of different taxa to the overall bacterial community provides an alternative to focusing on absolute numbers. The average percentage of total cells hybridizing the Domain Bacteria probe $(32 \%)$ is the same as that reported for planktonic cells in the Cuyahoga River of northeast Ohio (Liu \& Leff 2002), while, overall, in freshwater aquatic ecosystems, the value averages just over $50 \%$ and is highly variable (Bouvier \& del Giorgio 2003). Despite the similarities between our study and others in this regard, it is notable that in one of the study streams $(\mathrm{OH})$ the average percentage of total cells hybridizing the Domain Bacteria probe was greater than $100 \%$. This same phenomenon was reported earlier (interestingly, in a study done in the same stream) and was attributed to DAPI underestimating total cell numbers, perhaps because of DNA binding proteins produced during starvation (McNamara et al. 2003). In addition, differences in the types of filters used (polycarbonate vs. Anodisc) may affect the number of cells that are retained and enumerated.

The taxa examined accounted for on average $69 \%$ of the Domain Bacteria. In general, in freshwater systems the majority of cells in the Domain Bacteria are accounted for by the $\alpha, \beta, C F B$, and HGC groups (e.g Šimek et al. 2001, Araya et al. 2003), and this was also the case in this study. Of these taxa, generally, the most abundant in this study were the $\beta$ - and $\alpha$-Proteobacteria, which constituted on average 19.5 and $17.0 \%$ of the Domain Bacteria, respectively.

The DGGE results demonstrate that there were large differences in bacterial assemblage composition among the streams, while the intrastream variation 
was low (with different sites and replicates showing very similar patterns). The number of bands detected was generally similar among sites, with the exception of the SC stream, and is comparable to numbers detected in other streams. For example, Cody et al. (2000) found 7 to 20 bands in a South Carolina stream, while Xu \& Leff (2004) report 12 to 20 bands in a river in Ohio.

FISH and DGGE revealed somewhat inconsistent views of the bacterial communities examined. The number of bands detected by DGGE, though consistent with those in a variety of systems (e.g. Cody et al. 2000, Castle \& Kirchman 2004, Xu \& Leff 2004), seems low when placed in the context of studies, including this one, that find several taxa to be major contributors to the bacterial community using FISH. The number of bands detected by DGGE is variable but seems surprisingly low when taking into account that at least a certain number of major taxa have been detected in the freshwater systems that have been examined. Castle \& Kirchman (2004) reported 9 or fewer bands in estuarine samples and specifically address the differences between FISH and DGGE. They report that the $\beta$-Proteobacteria, although abundant in their estuarine samples based on FISH, were not detected via DGGE. A similar finding was reported for lake bacteria by Zwisler et al. (2003); others have found that DGGE can detect $\beta$-Proteobacteria, so this phenomenon does not appear to be important in all environments (Crump et al. 2003).

Overall, differences in environmental conditions among streams appear to be reflected in both the abundance of different taxa as well as the bacterial community composition. FISH data revealed, in some cases, large intrastream differences in abundance of certain taxa, while DGGE data showed few differences within a stream. This study demonstrates that the ability of single system studies to serve as the foundation of generalities about stream bacterial ecology is potentially limited by the large amount of variation among streams. In contrast, variation in DGGE results within a stream was comparatively low, suggesting that, at the level of resolution used in this study, intrastream variation is perhaps less important than interstream variation.

Acknowledgements. This study was supported by a National Science Foundation grant, DEB-0087051. We thank Savannah River Ecology Laboratory, Coweeta Hydrological Laboratory, Department of Biology at Virginia Commonwealth University, Trout Lake Station at University of Wisconsin, Kellogg Biological Station at Michigan State University, and Konza Prairie Biological Station at Kansas State University for providing access to study sites. We thank Amanda Brothers, Mark Crissman, Angela Lindell, Brian Kloeppel, Leonard Smock, Anne Wright, Tim Kratz, Stephen Hamilton, Walter Dodds, and Adam Leff for their assistance.

\section{LITERATURE CITED}

Amann RI, Krumholz L, Stahl DA (1990) Fluorescent-oligonucleotide probing of whole cells for determinative, phylogenetic, and environmental studies in microbiology. J Bacteriol 172:762-770

Amann RI, Ludwig W, Schleifer KH (1995) Phylogenetic identification and in situ detection of individual microbial cells without cultivation. Microbiol Rev 59:143-169

APHA (1996) Standard methods for the examination of water and wastewater, 15th edn. American Public Health Association, Washington, DC

Araya R, Tani K, Takagi T, Yamaguchi N, Nasu M (2003) Bacterial activity and community composition in stream water and biofilm from an urban river determined by fluorescent in situ hybridization and DGGE analysis. FEMS Microbiol Ecol 43:111-119

Battin TJ, Wille A, Sattler B, Psenner R (2001) Phylogenetic and functional heterogeneity of sediment biofilms along environmental gradients in a glacial stream. Appl Environ Microbiol 67:799-807

Bott TL, Brock JT, Dun CS, Naiman RJ, Ovink RW, Petersen RC (1985) Benthic community metabolism in 4 temperate stream systems: an inter-biome comparison and evaluation of the river continuum concept. Hydrobiologia 123:3-46

Bouvier T, del Giorgio PA (2003) Factors influencing the detection of bacterial cells using fluorescence in situ hybridization (FISH): a quantitative review of published reports. FEMS Microbiol Rev 44:3-15

Brosius J, Dull TJ, Sleeter DD (1981) Gene organization and primary structure of a ribosomal RNA operon from Escherichia coli. J Mol Biol 148:107-127

Brümmer IHM, Fehr W, Wagner-Döbler I (2000) Biofilm community in polluted rivers: abundance of dominant phylogenetic groups over a complete annual cycle. Appl Environ Microbiol 66:3078-3082

Castle D, Kirchman DL (2004) Composition of estuarine bacterial communities assessed by denaturing gradient gel electrophoresis and fluorescence in situ hybridization. Limnol Oceanogr 2:303-314

Cody DG, Heath RT, Leff LG (2000) Characterization of benthic bacterial assemblages in a polluted stream using denaturing gradient gel electrophoresis. Hydrobiologia 432:207-215

Crump BC, Kling GW, Bahr M, Hobbie JE (2003) Bacterioplankton community shifts in an arctic lake correlate with seasonal changes in organic matter source. Appl Environ Microbiol 69:2253-2268

Eiler A, Laggenheder S, Bertilsson S, Tranvik LJ (2003) Heterotrophic bacterial growth efficiency and community structure at different natural organic carbon concentrations. Appl Environ Microbiol 69:3701-3709

Gao X, Olapade OA, Kershner MW, Leff LG (2004) Algalbacterial co-variation in streams: a cross-stream comparison. Arch Hydrobiol 159:253-261

Gloeckner FO, Zaichikov E, Belkova N, Denissova L, Pernthaler J, Pernthaler A, Amann R (2000) Comparative 16S rRNA analysis of lake bacterioplankton reveals globally distributed phylogenetic clusters including an abundant group of actinobacteria. Appl Environ Microbiol 66:5053-5065

Gray LJ (1997) Organic matter dynamics in Kings Creek, Konza Prairie, Kansas, USA. J N Am Benthol Soc 16:50-54

Heuer H, Smalla K (1997) Application of denaturing gradient gel electrophoresis and temperature gradient gel electrophoresis for studying soil microbial communities. In: van Elsas JD, Trevors JT, Wellingon EMH (eds) Modern soil microbiology. Marcel Dekker, New York, p 353-373 
Jardillier L, Basset M, Domaizon I, Belan A, Amblard C, Richardot M, Debroas D (2004) Bottom-up and top-down control of bacterial community composition in the euphotic zone of a reservoir. Aquat Microb Ecol 35:259-273

Kirchman DL (2001) The ecology of Cytophaga-Flavobacteria in aquatic environments. FEMS Microbiol Ecol 39:91-100

Koetsier PL, McArthur JV, Leff LG (1997) Spatial and temporal response of stream bacteria to sources of dissolved organic carbon in a blackwater stream system. Freshw Biol 37:79-89

Leff LG (2000) Longitudinal changes in microbial assemblages of the Ogeechee River. Freshw Biol 43:605-615

Leff LG (2002) Stream microbiology. In: Bitton G (ed) Encyclopedia of environmental microbiology. Wiley \& Sons, New York, p 3015-3024

Leff LG, Meyer JL (1991) Biological availability of dissolved organic carbon along the Ogeechee River, Georgia, USA. Limnol Oceanogr 36:315-325

Leff LG, McArthur JV, Shimkets LJ (1993) Evaluation of sources of bacteria in coastal plain streams using gram staining. Arch Hydrobiol 126:461-468

Leff LG, Leff AA, Lemke MJ (1998) Seasonal changes in planktonic bacterial assemblages of two Ohio streams. Freshw Biol 39:129-134

Lemke MJ, Brown BJ, Leff LG (1997a) The response of three bacteria populations to pollution in a stream. Microb Ecol 34:224-231

Lemke MJ, McNamara CJ, Leff LG (1997b) Comparison of methods for concentration of bacterioplankton for in situ hybridization. J Microbiol Methods 29:23-29

Lemke MJ, Wickstrom CE, Leff LG (1997c) A preliminary study on the distribution of viruses and bacteria in lotic habitats. Arch Hydrobiol 141:67-74

Liu J, Leff LG (2002) Temporal changes in the bacterioplankton of a Northeast Ohio (USA) river. Hydrobiologia 489:151-159

Manny BA, Wetzel RG (1973) Diurnal changes in dissolved organic and inorganic carbon and nitrogen in a hardwater stream. Freshw Biol 3:341-343

Manz W, Amann R, Ludwig W, Magner M, Schleifer KH (1992) Phylogenetic oligodoxynucleotide probes for the major subclasses of Proteobacteria: problems and solutions. Syst Appl Microbiol 15:593-600

McArthur JV, Marzolf GR (1986) Interactions of the bacterial assemblages of a prairie stream with dissolved organic carbon from riparian vegetation. Hydrobiologia 134:193-200

McArthur JV, Leff LG, Smith MH (1992) Genetic diversity of bacteria along a stream continuum. J N Am Benthol Soc 11:269-277

McNamara CJ, Leff LG (2004) Response of biofilm bacteria to dissolved organic matter from decomposing maple leaves. Microb Ecol 48:324-330

McNamara CJ, Lemke MJ, Leff LG (2002) Culturable and nonculturable fractions of bacterial populations in sediments of a South Carolina stream. Hydrobiologia 482:151-159

McNamara CJ, Lemke MJ, Leff LG (2003) Underestimation of bacterial numbers in starvation-survival mode using the nucleic acid stain DAPI. Arch Hydrobiol 157:309-319

Meier H, Amann R, Ludwig W, Schleifer KH (1999) Specific oligonucleotide probes for in situ detection of a major group of gram-positive bacteria with low DNA $\mathrm{G}+\mathrm{C}$ content. Syst Appl Microbiol 22:186-196

Meyer JL (1990) A blackwater perspective on riverine ecosystems. BioScience 40:643-651

Meyer JL, Crocker T, D'angelo D, Dodds W, Findlay S, Oswood M, Repert D, Toetz D (1993) Stream research in the long-term ecological research network. Long-Term
Ecological Research (LTER) Network Office Publication No. 15, Seattle, WA

Muyzer G, De Waal EC, Uitterlinden AG (1993) Profiling of complex microbial populations by denaturing gradient gel electrophoresis analysis of polymerase chain reactionamplified genes coding for 16S rRNA. Appl Environ Microbiol 59:695-700

Olapade O, Leff LG (2005) Seasonal response of stream biofilm communities to dissolved organic matter and nutrient enrichments. Appl Environ Microbiol 71:2278-2287

Olapade O, Gao X, Leff LG (2005) Abundance of three bacterial populations in selected streams. Microb Ecol (in press)

Pearce DA, van der Gast CJ, Lawley B, Ellis-Evans JC (2003) Bacterioplankton community diversity in a maritime Antarctic lake, determined by culture-dependent and cultureindependent techniques. FEMS Microbiol Ecol 45:59-70

Roller C, Wagner R, Amann R, Ludwig W, Schleifer KH (1994) In situ probing of Gram-positive bacterial with a high DNA $\mathrm{G}+\mathrm{C}$ content by using 23S rRNA-targeted oligonucleotides. Microbiology 140:2849-2858

Selje N, Simon M (2003) Composition and dynamics of particleassociated and free-living bacterial communities in the Weser estuary, Germany. Aquat Microb Ecol 30:221-237

Šimek K, Armengol J, Comerma M, Garcia JC, Kojecka P, Nedoma J, Hejzlar J (2001) Changes in the epilimnetic bacterial community composition, production, and protistinduced mortality along the longitudinal axis of a highly eutrophic reservoir. Microb Ecol 42:359-371

Smock LA (1997) Organic matter dynamics in Buzzards Branch, a blackwater stream in Virginia, USA. J N Am Benthol Soc 16:54-58

Stahl DA, Amann R (1991) Development and application of nucleic acid probes in bacterial systematics. In: Stackebrandt E, Goodfellow M (eds) Nucleic acid techniques in bacterial systematics. Wiley, Chichester, p 205-248

ter Braak CJF (1988) Partial canonical correspondence analysis. In: Bock HH (ed) Classification and related methods of data analysis. North-Holland, Amsterdam, p 551-558

Trusova MY, Gladyshev MI (2002) Phylogenetic diversity of winter bacterioplankton of eutrophic Siberian reservoirs as revealed by $16 \mathrm{~S}$ rRNA gene sequences. Microb Ecol 44: $252-259$

Tsai Y, Olson BH (1992) Rapid method for separation of bacterial DNA from humic substances in sediments for polymerase chain reaction. Appl Environ Microbiol 58:2292-2295

van Elsas JD, Wolters AC (1995) Polymerase chain reaction (PCR) of soil microbial DNA. In: Akkermans DL, van Elsas JD, de Bruijn JD (eds) Molecular microbial ecology manual 2.7.2. Kluwer, Dordrecht, p 1-10

Webster JR, Meyer JL (1997) Organic matter budgets for streams: a synthesis. J N Am Benthol Soc 16:141-161

Webster JR, Meyer JL, Wallace JB, Benfield EF (1997) Organic matter dynamics in Hugh White Creek, Coweeta Hydrologic Laboratory, North Carolina, USA. J N Am Benthol Soc 16:74-78

Xu P, Leff LG (2004) Longitudinal changes in the benthic bacterial community of the Mahoning River (Ohio, USA). Hydrobiologia 522:329-335

Zhou JZ, Bruns MA, Tiedje JM (1996) DNA recovery from soils of diverse composition. Appl Environ Microbiol 62:316-322

Zwart G, Crump BC, Kamst-van Agterveld MP, Hagen F, Han SK (2002) Typical freshwater bacteria: an analysis of available 16S rRNA gene sequences from plankton of lakes and rivers. Aquat Microb Ecol 28:141-155

Zwisler W, Selje N, Simon M (2003) Seasonal patterns of the bacterioplankton community composition in a large mesotrophic lake. Aquat Microb Ecol 31:211-225 